\title{
Aktivitas Antioksidan Ekstrak Etanol Temu Blenyeh (Curcuma Purpurascens Blumae) Dengan Metode Dpph (1,1 Diphenyl-2-Picrylhydrazyl)
}

\author{
Oktariani Pramiastuti ${ }^{{ }^{*}}$, Fiqih Kartika Murti ${ }^{2}$, Sri Mulyati ${ }^{3}$, Ulfatun Khasanah ${ }^{4}$, \\ Rima Harsa Atqiya Alquraisi ${ }^{5}$, Ainun Afifah $^{6}$, Aisyah Khairunisa Nitha \\ Sundawa ${ }^{7}$, Ela Nandayani ${ }^{8}$, Yoga Pamungkas ${ }^{9}$ \\ $1,2,3,4,5,6,7,8,9$ Program Studi Farmasi Program Sarjana (S-1), STIKes Bhakti Mandala Husada \\ Slawi, Indonesia \\ *email: oktariani.pram@gmail.com
}

\begin{abstract}
Antioxidants have a function to scavenge and neutralize oxidation effect caused by free radicals by preventing the formation of radicals. Temu blenyeh (Curcuma purpurascens $\mathrm{BI}$ ) is one of the curcuma species which is still under-researched. Traditionally, temu blenyeh is used to treat stomachache, cough, itch, and skin infection. Some studies show that temu blenyeh extract had antioxidants activity and anti-cancer. The extract contains flavonoid, terpenoid, steroid, triterpenoid, essential oil. The study aimed to determine antioxidant activity of ethanol extract of temu blenyeh using DPPH method. Temu blenyeh was extracted by maceration with $96 \%$ ethanol solvent. The antioxidants activity test described that the value of $\mathrm{IC}_{50}$ was $48.697 \mathrm{ppm}$.
\end{abstract}

Keywords: Temu blenyeh, DPPH, antioxidants

\begin{abstract}
Abstrak
Antioksidan berfungsi untuk menangkal dan menetralisasi efek oksidasi yang disebabkan radikal bebas dengan cara mencegah terbentuknya radikal. Temu blenyeh (Curcuma purpurascens $\mathrm{Bl}$ ) salah satu spesies curcuma yang masih sedikit diteliti. Temu blenyeh secara tradisional digunakan untuk mengobati sakit perut, batuk, gatal, dan infeksi kulit. Beberapa penelitian membuktikan bahwa ekstrak rimpang temu blenyeh memiliki aktivitas antioksidan dan anti kanker. Temu blenyeh mengandung flavonoid, terpenoid, steroid, triterpenoid dan minyak esensial. Penelitian ini bertujuan untuk mengetahui adanya aktivitas antioksidan pada ekstrak etanol temu blenyeh menggunakan metode DPPH. Temu blenyeh diekstraksi dengan metode maserasi menggunakan pelarut etanol 96\%. Dalam penelitian uji aktivitas antioksidan ekstrak etanol temu blenyeh menunjukkan hasil nilai IC 50 sebesar 48,697 ppm.
\end{abstract}

Kata kunci : Temu blenyeh; DPPH; Antioksidan

\section{Pendahuluan}

Temu Blenyeh, (Curcuma purpurascens BI.) adalah sejenis tanaman obat anggota suku temu temuan (Zingiberaceae). Temu ini dikenal di Jawa Barat sebagai koneng pinggang atau tinggang, di Yogyakarta dikenal sebagai temu blenyeh, dan di Solo dikenal dengan temu glenyeh, atau temu bayi [1]. Curcuma purpurascens BI adalah salah satu tanaman yang kurang dikenal dalam spesies curcuma dan dianggap tidak penting [2].

Kandungan aktif lainnya dari temu blenyeh antara lain flavonoid, saponin, quinine dan triterpenoid [3]. Temu blenyeh merupakan tumbuhan dengan sejarah etnomedisinal kuno dimana penggunaannya telah terbukti memiliki kemampuan 


\section{Prosiding Seminar Nasional Kesehatan $\mathbf{2 0 2 1}$ Lembaga Penelitian dan Pengabdian Masyarakat Universitas Muhammadiyah Pekajangan Pekalongan}

substansial untuk pengobatan dari berbagai penyakit, seperti pengobatan luka, kudis, gatal-gatal, demam, batuk dan bisul [4][5], [6].

Senyawa antioksidan merupakan senyawa yang dapat meredam radikal bebas, serta menghambat terjadinya oksidasi pada sel tubuh, sehingga dapat mencegah atau mengurangi terjadinya kerusakan sel [7]. Radikal bebas adalah suatu senyawa atau molekul yang mengandung satu atau lebih elektron yang tidak berpasangan pada orbital luarnya. Adanya elektron tidak berpasangan menyebabkan senyawa tersebut sangat reaktif mencari pasangan, dengan cara menyerang dan mengikat elektron yang berada di sekitarnya sehingga dapat memicu timbulnya penyakit [8]. Akibat dari radikal bebas adalah sel menjadi rusak, dan menyebabkan berbagai jenis penyakit, seperti kanker, anemia, asma, artritis, inflamasi, degenerasi syaraf, parkinson, dan proses penuaan dini [9].

\section{Metode}

\section{Alat}

Alat yang digunakan pada penelitian ini antara lain cawan porselin, sarung tangan, talenan, spatula, timbangan analitik (Oshaus), blender (Philips), waterbath (DFS), oven (Mummert UN 160), alat-alat gelas (Pyrex) meliputi tabung reaksi, labu ukur, gelas ukur, erlenmeyer, corong, batang pengaduk, kaca arloji, gelas beaker dan pipet tetes. vortex (B-One), kertas saring, plastik wrapping, kertas saring, tissue, alumunium foil, micropipette, dan spektrofotometri UV-Vis (mini-1240 Shimadzu).

\section{Bahan}

Bahan yang digunakan dalam penelitian ini antara lain temu blenyeh, etanol $96 \%$ (teknis), metanol (teknis), methanol (p.a), vitamin C (teknis), dan DPPH (1,1-difenil2picrylhydrazyl) (p.a).

\section{Rancangan Penelitian}

Penelitian ini merupakan penelitian eksperimental yang bersifat analitik dengan berbagai perbandingan konsentrasi ekstrak etanol temu blenyeh (Curcuma soloensis) dengan tujuan untuk mengetahui dan membandingkan berapa nilai $\mathrm{IC}_{50}$ aktivitas antioksidan.

\section{Prosedur Penelitian}

Pada penelitian uji aktivitas antioksidan ekstrak etanol temu blenyeh (Curcuma soloensis) meliputi :

\section{Uji Aktivitas Antioksidan \\ Pembuatan Larutan DPPH 0,05 $\mu \mathrm{M}$}

DPPH ditimbang sebanyak $5 \mathrm{mg}$ kemudian dilarutkan dalam $250 \mathrm{~mL}$ metanol p.a. di dalam labu ukur $250 \mathrm{~mL}$ sehingga diperoleh larutan dengan konsentrasi 0,05 mM [10].

\section{Penentuan Panjang Gelombang Serapan Maksimum}

DPPH Sebanyak $4 \mathrm{~mL}$ larutan DPPH 0,05 $\mu \mathrm{M}$ dipipet, serapan diukur pada spektrofotometer UV-Vis pada panjang gelombang 400-800 nm dengan blanko [10]. 


\section{Prosiding Seminar Nasional Kesehatan 2021 Lembaga Penelitian dan Pengabdian Masyarakat Universitas Muhammadiyah Pekajangan Pekalongan}

\section{Penentuan Operating time (OT)}

Larutan DPPH 0,05 $\mu \mathrm{M}$ dimasukkan ke dalam tabung reaksi, masing-masing 4 $\mathrm{mL}$. Kemudian ditambahkan 0,2 mL larutan vitamin $\mathrm{C}$ dengan konsentrasi $100 \mathrm{ppm}$. Setiap tabung reaksi ditutup erat dengan dilapisi alumunium foil dan diinkubasi di tempat gelap dengan waktu yang berbeda yaitu 5 menit, 10 menit, 15 menit, 20 menit, 25 menit, 30 menit, 35 menit, 40 menit, 45 menit, 50 menit, 55 menit dan 60 menit. Absorbansi sampel vitamin $\mathrm{C}$ diukur pada panjang gelombang maksimum dengan blanko metanol [11].

\section{Penentuan Serapan Blanko}

Sebanyak 3,8 mL larutan DPPH 0,05 $\mu \mathrm{M}$ dipipet dan ditambahkan 0,2 $\mathrm{mL}$ metanol p.a. Setelah dibiarkan 12,5 menit, ditempatkan pada keadaan gelap dalam suhu kamar, serapan diukur pada spektrofotometer UV-Vis pada panjang gelombang $515 \mathrm{~nm}[10]$.

\section{Pembuatan Larutan Vitamin C}

Larutan stok vitamin C 100 ppm dibuat menurutdengan modifikasi. Sebanyak 10 $\mathrm{mg}$ serbuk vitamin $\mathrm{C}$ ditimbang dan dilarutkan dalam $100 \mathrm{~mL}$ metanol. Kemudian dibuat seri kadar vitamin $C$ dengan konsentrasi 8 ppm, 16 ppm dan 32 ppm.

\section{Pembuatan Larutan Sampel}

Sebanyak $100 \mathrm{mg}$ ekstrak temu blenyeh ditimbang dan dilarutkan $100 \mathrm{~mL}$ metanol sehingga didapatkan larutan stok sampel 1000 ppm. Dari larutan tersebut dilakukan pengenceran bertingkat untuk mendapatkan seri kadar larutan sampel ekstrak etanol temu blenyeh dengan konsentrasi 500 ppm, 250 ppm, dan 125 ppm.

\section{Pengukuran Aktivitas Antioksidan}

Penentuan aktivitas antioksidan, sebanyak 0,2 mL masing-masing larutan uji dipipet dengan pipet mikro ke dalam tabung reaksi kemudian tambahkan 3,8 $\mathrm{mL}$ larutan DPPH. Campuran larutan dihomogenkan dan dibiarkan selama 12,5 menit di tempat gelap dalam suhu ruang. Aktivitas antioksidan ekstrak ditentukan oleh besarnya hambatan serapan radikal bebas DPPH, dengan cara menghitung persentase inhibisi serapan DPPH [10]. Presentase inhibisi dihitung dengan rumus dibawah ini:

$$
\%=\frac{\text { Abs. Kontrol }- \text { Abs. Sampel }}{\text { Abs. kontrol }} \times 100 \%
$$

\section{Keterangan :}

Abs. Kontrol : Serapan radikal DPPH 0,05 $\mu \mathrm{M}$ pada panjang gelombang maksimum.

Abs. Sampel : Serapan radikal DPPH 0,05 $\mu$ M setelah ditambahkan larutan uji pada panjang gelombang serapan maksimum DPPH.

Kemudian dari hasil persen inhibisi dilakukan penbuatan kurva antara persen inhibisi dengan konsentrasi ekstrak etanol rimpang temu blenyeh dan untuk pembanding vitamin C. Dari kurva tersebut akan didapatkan persamaan linear yaitu $\mathrm{Y}=\mathrm{a}+\mathrm{bx}$ untuk menghitung besar nilai $\mathrm{IC}_{50}$. 


\section{Prosiding Seminar Nasional Kesehatan Lembaga Penelitian dan Pengabdian Masyarakat Universitas Muhammadiyah Pekajangan Pekalongan}

\section{Hasil dan Pembahasan}

Hasil

Tabel 1. Hasil Rata-rata \% Inhibisi Vitamin C

\begin{tabular}{cc}
\hline $\begin{array}{c}\text { Kadar } \\
(\mathrm{ppm})\end{array}$ & $\begin{array}{c}\text { Rata-rata \% } \\
\text { inhibisi }(\%)\end{array}$ \\
\hline 8 & 135,430 \\
16 & 160,649 \\
32 & 184,553 \\
\hline
\end{tabular}

Tabel 2. Hasil Rata-rata \% Inhibisi Ekstrak Etanol Temu Blenyeh (Curcuma purpurascens $\mathrm{BI}$.)

\begin{tabular}{cc}
\hline $\begin{array}{c}\text { Kadar } \\
(\mathrm{ppm})\end{array}$ & $\begin{array}{c}\text { Rata-rata \% } \\
\text { inhibisi }(\%)\end{array}$ \\
\hline 250 & 79,492 \\
500 & 132,026 \\
1000 & 150,827 \\
\hline
\end{tabular}

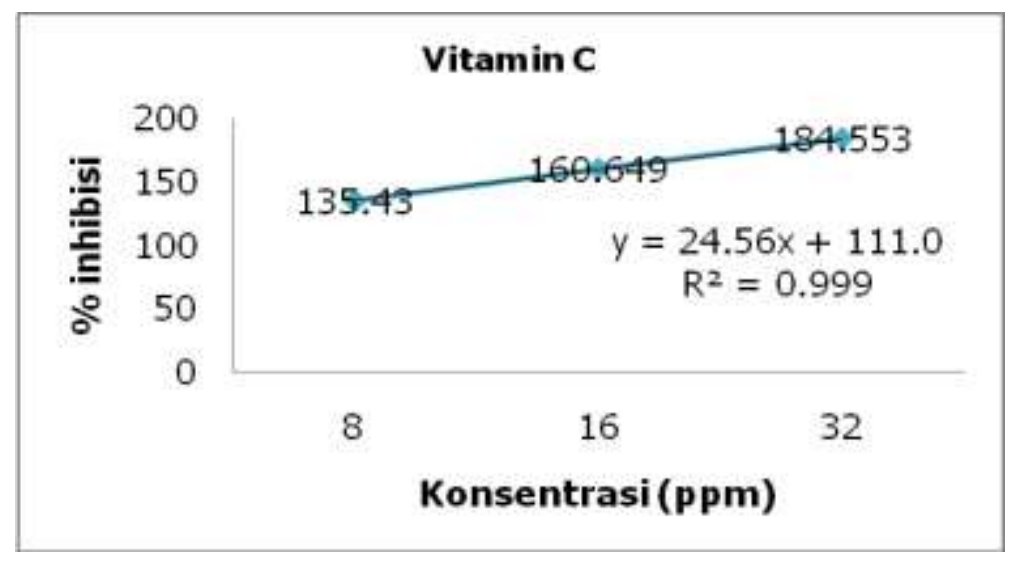

Gambar 1. Kurva Hubungan Konsentrasi Vitamin C Dengan Persen Inhibisi

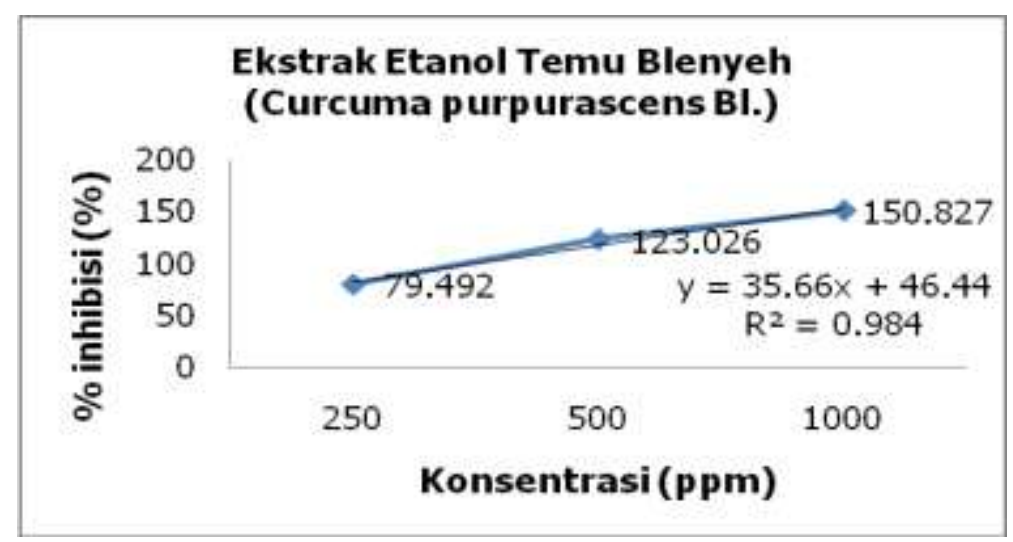

Gambar 2. Kurva Hubungan Konsentrasi Ekstrak Etanol Temu Blenyeh (Curcuma Purpurascens BI.) Dengan Persen Inhibisi 


\section{Prosiding Seminar Nasional Kesehatan 2021 Lembaga Penelitian dan Pengabdian Masyarakat Universitas Muhammadiyah Pekajangan Pekalongan}

\section{Pembahasan}

Pengujian aktivitas antioksidan secara kuantitatif dilakukan dengan menggunakan metode DPPH. Pemilihan penggunaan metode ini karena merupakan metode yang sederhana, mudah, cepat dan peka serta hanya memerlukan sedikit sampel untuk evaluasi aktivitas antioksidan dari senyawa bahan alam [12].

Prinsip pengukuran aktivitas antioksidan secara kuantitatif menggunakan metode DPPH berdasar pada adanya perubahan intensitas warna ungu DPPH yang sebanding dengan konsentrasi larutan DPPH tersebut. Radikal bebas DPPH yang memiliki elektron yang tidak berpasangan akan memberikan warna ungu. Warna akan berubah menjadi kuning saat elektronnya berpasangan. Perubahan warna ini mengakibatkan perubahan absorbansi pada panjang gelombang maksimum DPPH menggunakan spektrofotometri UV-Vis sehingga akan diketahui nilai aktivitas peredaman radikal bebas yang dinyatakan dengan nilai inhibitory concentration $\left(\mathrm{IC}_{50}\right)$ [13].

\section{Penentuan Panjang Gelombang Maksimum}

Penentuan panjang gelombang maksimum bertujuan untuk mengetahui panjang gelombang yang memiliki serapan paling maksimum [12]. Dari hasil penentuan panjang gelombang DPPH diperoleh panjang gelombang $515,8 \mathrm{~nm}$ pada absorbansi sebesar 0,469. Perbedaan panjang gelombang terjadi karena adanya perbedaan penggunaan pelarut dan deteksi alat pengukuran[14]. Absorbansi DPPH yang diperoleh sudah sesuai dengan pernyataan Gandjar \& Rohman (2007)[15] yang menyatakan bahwa absorban yang terbaca pada spektrofotometer hendaknya antara 0,2 sampai 0,8 .

\section{Penentuan Operating Time}

Lama penentuan operating time dilakukan dengan interval pengukuran absorbansi sampel setiap 5 menit selama 60 menit. Dalam pengukuran operating time digunakan sampel pembanding vitamin C dengan konsentrasi 100 ppm. Hasil penentuan operating time diperoleh absorbansi yang stabil mulai pada menit ke 5, 10, 15 , dan 20 dengan absorbansi sebesar 0,373. Sedangkan mulai pada menit ke 25 absorbansi yang dihasilkan sudah tidak stabil dengan menunjukkan adanya kenaikan absorbansi menjadi 0,374. Sehingga ditentukan waktu inkubasi sampel yang stabil selama 12,5 menit. Penentuan aktivitas antioksidan selanjutnya diukur dengan waktu inkubasi hasil penentuan operating time yaitu selama 12,5 menit.

\section{Penentuan Aktivitas Antioksidan}

Penentuan aktivitas antioksidan dilakukan pada panjang gelombang 515,8 nm dengan waktu inkubasi selama 12,5 menit, kemudian diukur serapannya dengan spektrofotometri UV-Vis. Peningkatan jumlah $\mathrm{DPPH}-\mathrm{H}$ ditandai dengan terjadinya perubahan warna larutan DPPH dari violet gelap menjadi kuning pucat atau tidak berwarna[13]. Penurunan intensitas warna yang terjadi disebabkan oleh berkurangnya ikatan rangkap terkonjugasi pada DPPH. Hal ini dapat terjadi apabila adanya penangkapan satu elektron oleh zat antioksidan, menyebabkan tidak adanya kesempatan elektron tersebut untuk beresonansi[16]. Reaksi mekanisme reduksi DPPH dapat dilihat pada gambar 1 . 


\section{Prosiding Seminar Nasional Kesehatan $\mid 2021$ Lembaga Penelitian dan Pengabdian Masyarakat Universitas Muhammadiyah Pekajangan Pekalongan}

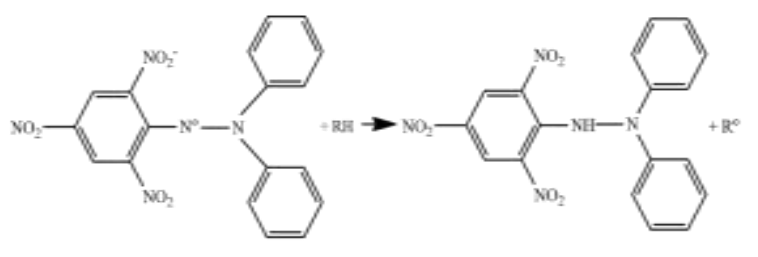

\section{Gambar 3. Reaksi DPPH Dengan Antioksidan [10]}

Pengujian aktivitas antioksidan pada sampel ekstrak etanol temu blenyeh dan vitamin $\mathrm{C}$ sebagai pembanding. Pada pengujian antioksidan vitamin $\mathrm{C}$ dibuat variasi konsentrasi $32 \mathrm{ppm}, 16 \mathrm{ppm}$, dan $8 \mathrm{ppm}$. Tujuan dari pembuatan variasi konsentrasi untuk mendapatkan persamaan regresi liner, sehingga diperoleh nilai $\mathrm{IC}_{50}$ dari sampel. Dari tiap konsentrasi vitamin $\mathrm{C}$ diambil sebanyak $0,2 \mathrm{~mL}$ dan ditambahkan larutan

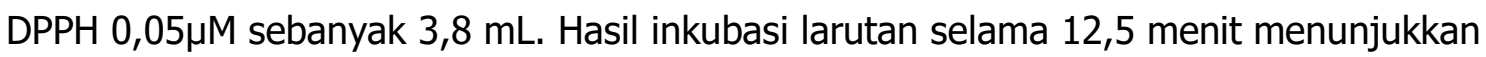
perubahan warna kuning pucat, yang kemudian diukur serapannya dengan spektrofotometri UV-Vis. Setiap replikasi dihitung persen inhibisi sampai diperoleh $\mathrm{IC}_{50}$. Hasil rata-rata persentase inhibisi vitamin $C$ dapat dilihat pada tabel 1.

Nilai $\mathrm{IC}_{50}$ vitamin $\mathrm{C}$ ditentukan dengan menggunakan persamaan regresi linier dari kurva hubungan konsentrasi sampel terhadap persen inhibisi dengan persamaan $Y=a x+b$, konsentrasi sampel ( $p p m$ ) sebagai sumbu $(X)$ dan nilai persentase inhibisi sebagai sumbu $(Y)$. Berdasarkan persamaan regresi linier $y=24,56 x+111$ dengan $R^{2}$ = 0,999 dari Gambar 2, hubungan antara konsentrasi hasil ekstrak terhadap persentase inhibisi, diperoleh nilai $\mathrm{IC}_{50}$ sebesar 45,480 ppm.

Pengujian aktivitas antioksidan dilakukan pada ekstrak etanol temu blenyeh dengan variasi konsentrasi 1000 ppm, 500 ppm, 250 ppm dan 125 ppm. Dari tiap konsentrasi ekstrak temu blenyeh sebanyak $0,2 \mathrm{~mL}$ dan ditambahkan larutan DPPH $0,05 \mu \mathrm{M}$ sebanyak 3,8 mL. Hasil inkubasi larutan selama 12,5 menit menunjukkan pengurangan intensitas warna ungu DPPH, yang kemudian diukur serapannya dengan spektrofotometri UV-Vis. Pengujian aktivitas antioksidan dilakukan replikasi sebanyak tiga kali. Hasil rata-rata persentase inhibisi ekstrak etanol temu blenyeh dapat dilihat pada tabel 2.

Nilai IC $_{50}$ ekstrak etanol temu blenyeh diperoleh dari persamaan $y=33,66 x+$ 46,44 dengan $\mathrm{R}^{2}=0,984$ sebesar $48,697 \mathrm{ppm}$. Dari nilai $\mathrm{IC}_{50}$ yang diperoleh pada ekstrak etanol temu blenyeh dan pembanding termasuk ke dalam kategori antioksidan sangat kuat. Menurut Setha,et al., (2013)[17] kategori aktivitas antioksidannya adalah sangat kuat karena memiliki nilai $\mathrm{IC}_{50}<50$ ppm. Besarnya aktivitas antioksidan ditandai dengan nilai $\mathrm{IC}_{50}$ yang menunjukkan konsentrasi sampel $(\mathrm{ppm})$ yang mampu menghambat proses oksidasi radikal DPPH sebesar $50 \%$. Semakin kecil nilai $\mathrm{IC}_{50}$ berarti semakin tinggi aktivitas antioksidannya [18].

Aktivitas antioksidan dibagi menjadi kategori sangat kuat, kuat, sedang, lemah, dan sangat lemah [13]. Antioksidan dikatakan sangat kuat apabila memiliki nilai $\mathrm{IC}_{50}$ kurang dari 50 ppm, antioksidan kuat memiliki nilai IC $_{50}$ berada pada kisaran 50 ppm hingga 100 ppm, antioksidan sedang memiliki nilai IC $_{50}$ berkisar antara 100 ppm hingga 150 ppm, antioksidan lemah memiliki kisaran 150 ppm hingga 200 ppm dan nilai IC $_{50}$ lebih dari 200 ppm merupakan antioksidan berkategori sangat lemah[19]. 


\section{Prosiding Seminar Nasional Kesehatan 2021 Lembaga Penelitian dan Pengabdian Masyarakat Universitas Muhammadiyah Pekajangan Pekalongan}

Dari hasil pengukuran aktivitas antioksidan ekstrak temu blenyeh, hasil tersebut lebih kuat bila dibandingkan dengan hasil penelitian terhadap tanaman spesies curcuma. Seperti yang dilakukan oleh Mariane., (2018)[20] yang menemukan aktivitas antioksidan dalam ekstrak rimpag temu giring (Curcuma heyneana) yakni sebesar 102,15 ppm. Serta penelitian oleh Widyastuti., (2020)[21] yang menemukan aktivitas antioksidan pada rimpang temu lawak (Curcuma xanthorizae) dari berbagai daerah berkisar 32,54 $\pm 0,92 \mu \mathrm{g} / \mathrm{mL}$ hingga 77,19 $\pm 0,74 \mu \mathrm{g} / \mathrm{mL}$. Sedangkan rimpang kunyit (Curcuma longa) memiliki aktivtas antioksidan sebesar 48,33 ppm [22] (septiana 2015).

\section{Kesimpulan}

Dari penelitian yang dilakukan uji aktivitas antioksidan pada ekstrak etanol temu blenyeh dengan metode DPPH memperoleh nilai $\mathrm{IC}_{50}$ sebesar $48,697 \mathrm{ppm}$ sedangkan nilai IC $_{50}$ vitamin $C$ sebesar 45,480 ppm sebagai pembanding. Perlu dilakukan penelitian lebih lanjut dengan metode yang berbeda seperti FRAP (Ferric Recucing Anyioxidant Power) CUPRAC dan bleaching terhadap ekstrak temu blenyeh dan pengembangan formulasi sediaan ekstrak temu blenyeh yang berpotensi sebagai antioksidan.

\section{Ucapan Terima Kasih}

Penelitian ini dapat dilaksanakan dengan baik berkat bantuan dari berbagai pihak, untuk itu peneliti mengucapkan terimakasih kepada Kementrian Pendidikan, Kebudayaan, Riset dan Teknologi, Direktorat Jendral Pendidikan Tinggi, Direktorat Sumber Daya; LLDIKTI Wilayah VI; STIKes Bhakti Mandala Husada Slawi yang telah memberikam kerjasama yang baik.

\section{Referensi}

[1] L. S. Hong et al., "Essential oil content of the rhizome of curcuma purpurascens $\mathrm{BI}$. (Temu Tis) and its antiproliferative effect on selected human carcinoma cell lines," Sci. World J., 2014, doi: 10.1155/2014/397430.

[2] K. V. K. Rao, N. M. Nawal M. Boukli, T. Samikkannu, L. A. Cubano, B. K. Dakshayani, and M. P. N. Nair, "Proteomics Profiling and Cytotoxic Effect of Curcuma longa on Prostate Cancer," Open Proteomics J., vol. 4, no. 1, pp. 1-11, 2011, doi: $10.2174 / 1875039701104010001$.

[3] E. Sinaga, Suprihatin, and M. R. Rastuti, "Kadar Flavonoid Total, Daya Antioksidan dan Daya Hepatoprotektif Ekstrak Etanol Rimpang Temu Tis (Curcuma purpurascens)," in Konggres XX dan Pertemuan IImiah Tahunan Ikatan Apoteker Indonesia 2018, 2018, p. 13, [Online]. Available: http://repository.unas.ac.id/1570/1/B20-Prosiding-PIT-2018.pdf.

[4] S. Z. Moghadamtousi, M. N. A. Kamarudin, C. K. Chan, B. H. Goh, and H. A. Kadir, "Phytochemistry and biology of loranthus parasiticus merr, a commonly used herbal medicine," Am. J. Chin. Med., vol. 42, no. 1, pp. 23-35, 2014, doi: 10.1142/S0192415X14500025. 


\section{Prosiding Seminar Nasional Kesehatan Lembaga Penelitian dan Pengabdian Masyarakat Universitas Muhammadiyah Pekajangan Pekalongan}

[5] F. Hajiaghaalipour, M. S. Kanthimathi, M. A. Abdulla, and J. Sanusi, "The Effect of Camellia sinensis on Wound Healing Potential in an Animal Model," vol. 2013, 2013.

[6] E. Rouhollahi et al., "Curcuma purpurascens BI. rhizome accelerates rat excisional wound healing: Involvement of Hsp70/Bax proteins, antioxidant defense, and angiogenesis activity," Drug Des. Devel. Ther., vol. 9, pp. 58055813, 2015, doi: 10.2147/DDDT.S88196.

[7] M. Abdul, Peranan radikal bebas dan antioksidan dalam kesehatan dan penyakit. 2003.

[8] T. Sunarni, S. Pramono, and R. 2007 Asmah, Flavonoid antioksidan penangkap radikal dari daun kepel (Stelechocarpus burahol). 2007.

[9] T. Amanda, D. Wewengkang, and A. Yudistira, "Uji Aktivitas Antioksidan Ekstrak Etanol Kulit Batang Mahoni ( Swietenia mahagoni jacq .) Menggunakan Metode DPPH," vol. 8, pp. 548-555, 2019.

[10] D. A. Juwita, H. Mukhtar, and R. K. Putri, "Uji Antioksidan Ekstrak Etanol Kulit Buah dan Daging Buah Menteng (Baccaurea racemosa (Blume) Mull. Arg.) dengan Metode DPPH (2,2 Diphenyl-1-picrylhydrazyl)," Sci. J. Farm. dan Kesehat., vol. 10, no. 1, p. 56, 2020, doi: 10.36434/scientia.v10i1.214.

[11] N. Rachmani, E. Prasasti, S. Pramono, and A. E. Nugroho, "Aktivitas Antioksidan Fraksi Flavonoid Bebas Andrografolid Dari Herba Sambiloto (Andrographis paniculata)," J. Farm. Medica/Pharmacy Med. J., vol. 1, no. 2, pp. 42-49, 2018, doi: 10.35799/pmj.1.2.2018.21642.

[12] P. E. S. K. Yuda, E. Cahyaningsih, and N. P. Y. Winariyanthi, "Skrining Fitokimia dan Analisis Kromatografi Lapis Tipis Ekstrak Tanaman Patikan Kebo (Euphorbia hirta L.)," J. IIm. Medicam., vol. 3, no. 2, pp. 61-70, 2017, doi: 10.36733/medicamento.v3i2.891.

[13] P. Molyneux, "The use of the stable free radical diphenylpicryl- hydrazyl (DPPH) for estimating antioxidant activity," Songklanakarin J. Sci. Technol., vol. 26, no. June 2003, pp. 211-219, 2004, doi: 10.1287/isre.6.2.144.

[14] J. R. Hidayati, A. Ridlo, and R. Pramesti, "Aktivitas Antioksidan Ekstrak Rumput Laut Padina sp. Dari Perairan Bandengan Jepara Dengan Metode Transfer Elektron," Bul. Oseanografi Mar., vol. 6, no. 1, p. 46, 2017, doi: 10.14710/buloma.v6i1.15742.

[15] I. G. Gandjar and A. Rohman, Kimia Farmasi Analisis., Cetakan ke. Pustaka Pelajar, 2009.

[16] K. Sayuti and R. Yenrina, "Mekanisme Kerja Antioksidan," Antioksidan, Alami dan Sint., pp. 73-74, 2015.

[17] B. Setha, F. F. Gaspersz, A. P. S. Idris, S. Rahman, and M. N. Mailoa, "Potential Of Seaweed Padina Sp. As A Source Of Antioxidant," Int. J. Sci. Technol. Res., vol. 2, no. 6, pp. 221-224, 2013. 


\section{Prosiding Seminar Nasional Kesehatan Lembaga Penelitian dan Pengabdian Masyarakat Universitas Muhammadiyah Pekajangan Pekalongan

[18] N. C. E. Setiawan and A. Febriyanti, "Aktivitas Antioksidan Ekstrak Etanol dan Fraksi-fraksi Umbi Eleutherine palmifolia (L.) Merr Dengan Metode DPPH," JCPS, vol. 1, no. 1, pp. 2598-2095, 2017.

[19] D. Purwanto, S. Bahri, and A. Ridhay, "Issn: 2477-5398 uji aktivitas antioksidan ekstrak buah purnajiwa (," KOVALEN J. Ris. Kim., vol. 3, no. April, pp. 24-32, 2017.

[20] M. Marianne, P. Patilaya, and B. T. Barus, "Uji Aktivitas Antioksidan Kombinasi Ekstrak Etanol Rimpang Temu Giring (Curcuma Heyneana) dan Daun Pugun Tanoh (Curanga Fel-Terrae) Menggunakan Metode Diphenyl Picrylhydrazil(DPPH)," Talent. Conf. Ser. Trop. Med., vol. 1, no. 2, pp. 398-404, 2018, doi: 10.32734/tm.v1i2.223.

[21] I. Widyastuti, H. Z. Luthfah, Y. I. Hartono, R. Islamadina, A. T. Can, and A. Rohman, "Antioxidant Activity of Temulawak (Curcuma xanthorrhiza Roxb.) and its Classification with Chemometrics," Indones. J. Chemom. Pharm. Anal., vol. 02, no. 1, p. 29, 2020, doi: 10.22146/ijcpa.507.

[22] E. Septiana and P. Simanjuntak, "Aktivitas Antimikroba dan Antoksidan Ekstrak Beberapa Bagian Tanaman Kunyit (Curcuma longa)," Fitofarmaka, vol. 5, no. 1, pp. 31-40, 2015, [Online]. Available: http://ci.nii.ac.jp/naid/120005619654/. 